\title{
NOTES
}

\section{TAXATION OF PREPAID INCOME: A TEMPORARY SOLUTION}

TAXPAYERS with prepaid income ${ }^{1}$ occasion judicial confusion over the nature of accrual accounting. ${ }^{2}$ Most courts implicitly assume that income may accrue prior to or upon receipt but never afterwards. ${ }^{3}$ Thus, compensation earned through performance is taxable upon the acquisition of a right to its receipt, ${ }^{4}$ while money obtained in advance of performance is taxable upon receipt. ${ }^{5}$ In

1. "The term 'prepaid income' means any amount ... which is received in connection with, and is directly attributable to, a liability which extends beyond the close of the taxable year in which such amount is received." INT. REv. CoDE of 1954, § 452(e) (1), 68A Stat. 152, later repealed by 69 Stat. 134 (1955). See cases cited note 5 infra. See also Sporrer, The Past and Future of Deferring Income and Reserving for Expenses, 34 TAxEs 45, 46 (1956) : "Prepaid income generally consists of the receipt of amounts for services or goods during a period prior to that in which it may unequivocally be regarded as income."

2. Business taxpayers generally employ the accrual basis of accounting. See Blatrmachr \& Knapp, Accounting Periods and Accounting Methods 24 (Practising Law Inst. 1955). Under the accrual system, earning rather than receipt of payment determines inclusion in gross income. See Finney \& Oldberg, LawyeR's Guide to Accounting 49 (1955); Grant, Basic Accounting and Cost Accounting 22 (1956). The cash basis of accounting-whereby income is determined by reporting revenue upon actual receipt and deducting expense at the time of actual payment-is highly misleading for firms with substantial inventories, fixed assets and/or a large volume of credit transactions. See U.S. Treas. Reg. 118, \& 39.41-2 (1953); Magrlo, Taxable Income 197 (rev. ed. 1945). On the cash system generally, see BLATTMACHR \& KNAPp, op. cit. supra at 34-36.

3. See, $\epsilon . g$., cases cited note 5 infra; see also Comment, Taxing Unsettled Income: The "Clain of Right" Test, 58 Yale L.J. 955, 959 n.20 (1949) (collecting authorities). The accrual taxpayer reports income or deducts expenses in the year accrued. In ordering taxation of prepayments upon receipt, courts have ignored the relationship between accrual and earning. The effective result has been to designate receipt as the final point for accruing prepayments.

4. See Spring City Foundry Co. v. Commissioner, 292 U.S. 182 (1934) ; 2 Mertens, Federal InCOMe TaXation $\S 12.60$, at $127 \mathrm{n} .72$ (1955) (hereinafter cited as MERTENs). Income does not accrue until the right to receive it becomes fixed and certain. See Spring City Foundry Co. v. Commissioner, sttpra; United States v. Harmon, 205 F.2d 919 (10th Cir. 1953); Georgia School-Book Depository, Inc., 1 T.C. 463 (1943); 2 Mertens $\S 12.60$ (must be an existing, liquidated amount). On collectibility and other elements of uncertainty, see Holland, Accrual Problems in Tax Accounting, 48 Mich. L. Rev. 149 (1949). The right to receive doctrine has been employed in the context of an obligation established through contractual performance. See, e.g., Georgia School-Book Depository, Inc., supra (court stressed that petitioner had already earned brokerage fees and right to payment therefore existed); 2 Mertens $\$ 12.61$; Stanley \& Kilcullen, The Federal InCOME TAx 190 (3d ed. 1955) (using "right to receive" synonymously with "earning").

5. See Clay Sewer Pipe Ass'n v. Commissioner, 139 F.2d 130 (3d Cir. 1943) (subscriptions for promotion campaign to be consummated in following years); South Dade 
the latter case, the doctrinal justification for using receipt as tax-determinative is that the recipient of advance payments takes them under a "claim of right without restriction as to their disposition." 6 But this rationale misconstrues the accrual system, which is founded on the premise that the clearest reflection of income is obtained by matching, in a given period, expenses and related rev-

Farms, Inc. v. Commissioner, 138 F.2d 818 (5th Cir. 1943) (advance rent) ; Astor Holding Co. v. Commissioner, 135 F.2d 47 (5th Cir. 1943) (same); Renwick v. United States, 87 F.2d 123 (7th Cir. 1936) (same); Curtis R. Andrews, 23 T.C. 1026 (1955) (advance fees for dance lessons); Wallace A. Moritz, 21 T.C. 622 (1954) (deposits paid on undeveloped photographs) ; DoAll Tulsa Co., 8 CCH Tax Ct. Mem. 343 (1949) (sales-service commissions) ; National Airlines, Inc., 9 T.C. 159 (1947) (advance sale of transportation tickets); South Tacoma Motor Co., 3 T.C. 411 (1944) (proceeds from sale of coupons entitling bearer to garage services performed in later years); Northern IIl. College of Optometry, 2 CCH Tax Ct. Mem. 664 (1943) (tuition paid in advance); Sporrer, supra note 1 , at $46-47$ (collecting cases). On the importance of receipt, see Your Health Club, Inc., 4 T.C. 385 (1944), discussed note 6 infra.

6. Clay Sewer Pipe Ass'n v. Commissioner, supra note 5, at 132; Curtis R. Andrews, supra note 5 , at 1032-33. See also other cases cited note 5 supra. The claim of right doctrine was originally formulated in North Am. Oil Consol. v. Burnet, 286 U.S. 417, 424 (1932) : "If a taxpayer receives earnings under a claim of right and without restriction as to its disposition, he has received income which he is required to return [i.e., to report], even though it may still be claimed that he is not entitled to retain the money, and even though he may still be adjudged liable to restore its equivalent." The doctrine arose in the context of disputes over the ownership of money. A taxpayer was held to have income upon the receipt of payments which he treated as his own under an asserted claim to absolute ownership. See 2 Mertens $\$ 12.103$. The fact that title was in dispute and the payments therefore might later be recovered did not change their categorization as income. See United States v. Lewis, 340 U.S. 590 (1951) (bonus received as compensation for services was fully taxable in the year received, though subsequently returned in part to the employer); Security Flour Mills Co. v. Commissioner, 321 U.S. 281 (1944) (since taxpayer did not have to deliver goods or perform services after the year of receipt, payments reportable in that year despite possibility of partial refunds); Brown v. Helvering, 291 U.S. 193 (1934) (commissions received were reportable in the year of receipt despite possibility of having to refund them in part, as no further services were to be rendered); North Am. Oil Consol. v. Burnet, supra (money received as profits from oil land, title to which was in dispute, reportable in year of receipt) ; Comment, 58 YALE L.J. 955, 960 nn.25, 26 (1949) (collecting cases). But see Commissioner v. Turney, 82 F.2d 661 (5th Cir. 1936) (money received not included in income even though taxpayer asserts a claim to it if the claim is unfounded on its face).

These cases all involved taxpayers who had already received the payments. Although the original statement of the doctrine was in a case involving an accrual taxpayer, the Supreme Court specifically insisted upon receipt. See North Am. Oil Consol. v. Burnet, supra at 424; Comment, 58 YALE L.T. 955, 958-59 (1949). But the Tax Court has indicated that an accrual taxpayer's present right to receive and unrestrictedly use advance payments might constitute a claim of right. See Your Health Club, Inc., supra note 5 (applying the doctrine to advance fees for treatment, partially unpaid, but which were all due). The claim of right doctrine is based on a "bird in hand" policy-taxes should be paid as soon as the taxpayer receives the money. See Bierman \& Helstein, Accounting for Prepaid Income and Estinated Expenses Under the Internal Revenue Code of 1954, 10 TAX L. REv. 83, 86 (1954). The application in Your Health Club, Inc., supra note 5, to fees owed but not yet received would therefore seem to be incorrect. See also note 10 
enue. ${ }^{7}$ Under accounting theory, therefore, proper inclusion of prepayments in accrued gross income requires not only the assertion of a right to their unrestricted use but also that the taxpayer have earned such payments by fulfilling the contractual obligations underlying their receipt. ${ }^{8}$

This difference between the judicial and accounting methods of ascertaining taxable income is of practical consequence whenever payment is a condition precedent to performance in later years. ${ }^{9}$ Basing taxation strictly upon the exist-

infra, listing authorities criticizing the application of a claim of right test to unearned prepayments on receipt.

Even before the "claim of right" theory was articulated in North Am. Oil, courts denied deferments of prepaid income. See United States v. Boston \& Prov. R.R., 37 F.2d 670 (1st Cir. 1930) (advance rent reportable in year of receipt); Automobile Underwriters, Inc., 19 B.T.A. 1160 (1930) (membership fees for services to be rendered over three years are reportable in year received); O'Day Inv. Co., 13 B.T.A. 1230 (1928) (advance rent received not allowed to be spread over the term of the lease). These decisions were grounded on the judiciary's supposed lack of authority to allow deferments. See Gelfand, The "Claim of Right" Doctrine, 33 TAxes 726 (1955).

7. See Blattarachr \& Knapp, op. cit. supra note 2, at 44; Paton, Accountants' HANDBook 113-14 (3d ed. 1945). In United States v. Anderson, 269 U.S. 422,440 (1926), the Supreme Court stated that: "It [the accrual method] was to enable taxpayers to keep their books and make their returns according to scientific accounting principles, by charging against income earned during the taxable period, the expenses incurred in and properly attributable to the process of earning income during that period ...." See also Security Flour Mills Co. v. Commissioner, supra note 6; Aluminum Castings Co. v. Routzahn, 282 U.S. 92,99 (1930); American Nat'l Co. v. United States, 274 U.S. 99, 104 (1927). But cf. 2 MERTENS $\S 12.23$ (the niceties of ideal accounting-matching expense against the revenue it helped to create-must frequently yield to the need for revenue and a workable system of taxation).

8. See Finnex \& OldBeRg, op. cit. supra note 2, at 49; Grant, op. cit. supra note 2, at $22 ; 2$ MERTENS $\S 12.01$.

9. Although a liability remains, money received as a condition precedent is held under a legal right. Moreover, if payment has not been made, the taxpayer may sue for it irrespective of his lack of performance. See 3 Corbin, Contracts \& 676 (1951) ; SimrpSON, Contracts $\S 117$ (1954); see also cases cited note 5 sipra. But commentators have argued that the taxpayer is restricted in his disposition of advance payments, and therefore the claim of right doctrine is inapplicable. They emphasize that the taxpayer must of necessity hold prepayments in reserve for the future expenses to be incurred in performance. Three factors are stressed. "First, the moral obligation which businessmen feel to carry out their commitments whether or not legally bound to do so. Second, the controlling business obligation to keep one's contracts or be forced out of business. Third, the legal enforcible obligation to furnish the service." Montgomery, Administrative Tax Accounting Fallacies in Section 41, 78 J. Accountancy 14, 17 (1944). See also Wagman, Sections 452 and 462: Stormy Past but a Bright Tomorrow, 33 TAxes 711, 714 (1955).

Defined in this manner, the claim of right doctrine would incorporate the accounting definition of prepaid income. See note 1 supra. But courts consider only legal limitations in determining whether a claim of right exists. Harold Bell Co., $14 \mathrm{CCH}$ Tax Ct. Mem. 343 (1955) (plaintiff argued advance payments needed for business expansion in order to keep present customer; court held payments unrestricted as to disposition since not specifically "earmarked").

Choice between the judicial or accounting method of ascertaining taxable income is often of no practical import because the existence of a contractual right to payment is often 
ence of a claim of right then forces the accrual taxpayer to report income before the year in which it is earned. Nevertheless, most courts have consistently adhered to the rule that advances which are prepayments held under the assertion of absolute ownership, rather than deposits kept in a "trust fund," are reportable when received..$^{10}$ So employed, the claim of right theory requires tax reporting which fails to reflect the taxpayer's actual earnings, and hence can cause an overall increase in his taxes. ${ }^{11}$ On the return for the first year in which he accepts advance payments for performance over several years, the taxpayer's net income will be unrealistically high. Although all prepayments received during that year must be included in gross income, a deduction for estimated future expenses incident to earning the payments is not allowed. ${ }^{12}$ On subsequent tax

concurrently dependent upon performance. See 3 CoRBrN, op. cit. supra at $\$ \$ 629,676$. And even when one of the events exists as a condition precedent to the other, both are commonly satisfied within the same accounting period. This is especially true under the accrual system where delay in actual payment is unimportant so long as a right to the payment exists. See note 4 supra and accompanying text.

10. See note 5 supra. The application of the claim of right doctrine to prepayments has been severely criticized. See Beacon Publishing Co. v. Commissioner, 218 F.2d 697, 699-701 (10th Cir. 1955); Gelfand, supra note 6; Wolder, Deduction of Reserves for Future Expenses and Deferring of Prepaid Income, 34 TAxes 524 (1956). The doctrine originated in the context of disputes over the ownership of funds already earned. See note 6 supra. But no dispute exists as to the taxpayer's right to the prepayments. Once it is ascertained that advance receipts are prepayments, i.e., not restricted as to use, the doctrine has fulfilled its function-determining whether the advances are subject to tax. Claim of right should not be further extended to insist that the prepayments are taxable upon receipt. See note 9 sutpra.

For cases in which advances fell outside the claim of right criterion because the taxpayer did not have unrestricted use of the money held by him, see Clinton Hotel Realty Corp. v. Commissioner, 128 F.2d 968 (5th Cir. 1942) (deposit held by landlord not gross income because of contractual requirement that it serve as security for performance under lease); The Seven-Up Co., 14 T.C. 965 (1950). (receipts earmarked and set aside in a specified fund) ; Leedy-Glover Realty and Ins. Co., 13 T.C. 95 (1949) (property insurance policies placed in escrow and released to petitioner ratably over policy life not reportable until released); Sporrer, supra note 1, at $46-47$ (collecting cases). The suggestion has been made that a change in terminology might permit proper accounting. "If so, it might be possible to avoid taxation upon receipt of items if called 'advances applicable to future operations' or simply 'prepaid items." Id. at 48.

11. See authorities cited note 5 supra. See also Beacon Publishing Co. v. Commissioner, supra note 10, at 699-700; Gelfand, supra note 6; Hoffman, Accounting Treatment Counts in Determining Net Taxable Income, 35 TAxes 918 (1957); Wagman, supra note 9 , at 713-14.

12. See notes 5 supra, 20, 22 infra, and cases cited therein. Assume that a new automobile club, organized in November 1957, keeps its books on a calendar-year basis and that one-hundred members joined the club on December 1, 1957, each paying $\$ 12$ annual dues in advance. The club expects to incur average expenses of $90 \mathrm{k}$ per month for each member, or a total expense for the entire group of $\$ 1080$ over a twelve month period. Out of the $\$ 1200$ collected in December, $\$ 120$ would represent future profits. Utilizing correct accounting, the club would take $\$ 100$ ( $\$ 1$ per member) into income for 1957 and, after deducting expenses of $\$ 90$ incturred in December 1957, would have a net income of $\$ 10$ for that year. In the following year the remaining $\$ 110$ of the income would be earned and 
returns, each year's prepaid income will be partially offset by the deduction of current expenses attributable to prepayments taxed in prior years. Even then, however, the failure of the claim of right theory to correlate each item of income with its related expense will distort fluctuations in the taxpayer's net income. ${ }^{13}$ For example, when low current expenditures, attributable to a prior low income year, are deducted from a high prepaid income of the current year, the taxpayer's adjusted gross income for the current year is inflated. Suppose, on the other hand, that he terminates his business activities; prepaid income will no longer be received but will only be earned, and the taxpayer will have losses in an amount equal to current expenditures attributable to previously taxed income. But the loss deduction will then be of no value to him, unless he has outside income against which to apply it or can utilize loss carryback provisions. ${ }^{14}$ Consequently, present imposition of the claim of right theory on prepaid income fosters continually inaccurate accrual tax reporting under which net income more nearly represents cash flow than actual earnings. ${ }^{\mathbf{1 5}}$

To eliminate this inaccuracy and correlate tax reporting with accounting

taxed. But, under the Commissioner's method, the club would be required to pay a federal income tax for 1957 on a fictitious taxable income of $\$ 1110-\$ 1200$ dues collected in December 1957 minus $\$ 90$ expenses incurred in that month.

13. Assume that future expenses related to prepaid income average $50 \%$ of the prepaid income, that these expenses are incurred in the year following receipt, and that the prepaid income is earned during the year following receipt. The following illustrates how fluctuations will be distorted by application of a strict claim of right basis as compared with deferred income reporting under accrual accounting:

\begin{tabular}{lccccc} 
& Prepaid & Present & Future & \multicolumn{2}{c}{ Adjusted Gross Income } \\
Ycar & Income & Expenses & Expenses & (Accrual) & (Clain of Right) \\
1952 & $\$ 200,000$ & $\$$ & $\$ 100,000$ & $\$$ & $\$ 200,000$ \\
1953 & 100,000 & 100,000 & 50,000 & 100,000 & \\
1954 & 300,000 & 50,000 & 150,000 & 50,000 & 250,000 \\
1955 & & 150,000 & & 150,000 & $(150,000)$
\end{tabular}

See Bierman \& Helstein, sitpra note 6, at $88-89$.

14. If his gross income is not as great as the deductible loss, the taxpayer will not derive full benefit from the deduction. The net operating loss for a taxable year ending after 1953 may, however, be carried back two years, INT. REv. CoDE of 1954, $\$ 172$ (b) (1) (A), or carried forward five years, $i d$. $\$ 172(\mathrm{~b})(1)$ (B). But this factor is a minor consideration because the taxpayer's carryover advantage is of dubious deductibility in the hands of a new owner. It will therefore probably have little, if any, effect on the sales price of the business. Id. $\$ \$ 381,382$. See Bitrker, Federal Income Estate and Gift TAXATION 473-74, 718 (1955) ; 5 MEERTENS $\$ 29.11$. For discussion of further limitations on the value of loss carryovers and carrybacks due to computation difficulties, see $5 \mathrm{id}$. $\S \$ 29.02-.05$.

15. The Commissioner's application of the claim of right doctrine "limits the accrual method to that class of cases where money has been earned and the right to it has been fixed, but the receipt is delayed to a subsequent taxable period. . . . It would permit the collection of taxes during periods not contemplated by the accrual method of accounting, and force the taxpayer into a cash receipts basis for all prepaid items." Beacon Publishing Co. v. Commissioner, 218 F.2d 697, 700-01 (10th Cir. 1955). 
theory, ${ }^{16}$ Congress, in 1954, passed two short-lived sections of the Internal Revenue Code- -452 and 462.17 Section 452 permitted an accrual taxpayer to defer including advance payments in gross income until they were earned. ${ }^{18}$ Section 462 allowed the deduction of anticipated expenses for which a present obligation existed; 19 advance payments were still includible in gross income upon receipt, but reserves for estimated future expenditures attributable to earning the payments could be deducted. ${ }^{20}$ Consequently, although section 462 did not grant the accrual taxpayer the power to postpone taxation of prepaid income until it was earned, he could at least have reported his prepayments on

16. In his 1954 State of the Union Message, cited in S. REP. No. 372, 84th Cong., 1st Sess. 3 (1955), President Eisenhower recommended that: "Tax accounting should be brought more nearly in line with accepted business accounting by allowing prepaid income to be taxed as it is earned rather than as it is received, and by allowing reserves to be established for known future expenses." See also S. REP. No. 1622, 83d Cong., 2d Sess. 62 (1954) (recognizing that court decisions have created divergencies requiring reconciliation of the computation of income for tax purposes and business purposes).

17. Int. Rev. Code of 1954, § 452, 68A Star. 152, later repealed by 69 Stat. 134 (1955) (hereinafter cited as $\S 452$ ) ; INT. REv. CoDE of 1954, § 462, 68A STAT. 158, later repealed by 69 Stat. 134 (1955) (hereinafter cited as $\S 462$ ). For an analysis and discussion of $\$ \S 452$ and 462 , see Wolder, supra note 10 . And for a discussion of the relationship between the two sections, see note 21 infra.

18. Section 452 specifically envisaged deferral of such items as rentals, club dues and warehouse fees. See H.R. REP. No. 1337, 83d Cong., 2d Sess. 48 (1954). A single item of prepaid income could not be deferred over a period greater than six years. "In the case of any prepaid income to which this section applies, if the liability ... is (at the time the income is received) to end before the first day of the sixth taxable year after the taxable year in which received, then such income shall be included in gross income for the taxable year in which received, and for each of the 5 succeeding taxable years, to the extent proper under the method of accounting used under section 446 in computing taxable income for such year." $\$ 452$ (a) (1). "In the case of any prepaid income ... if the liability ... is (at the time the income is received) to end after the close of the fifth taxable year after the taxable year in which such income is received, then-(1) one-sixth of the prepaid income shall be included in gross income for the taxable year in which received, and one-sixth shall be included in gross income for each of the 5 succeeding taxable years ...." $\$ 452$ (b). See Bierman \& Helstein, supra note 6, at 93-103.

19. "In computing taxable income for the taxable year, there shall be taken into account (in the discretion of the Secretary or his delegate) a reasonable addition to each reserve for estimated expenses ...." \& 462(a). "Estimated expense" was defined as a deduction "(A) part or all of which would ... be required to be taken into account for a subsequent taxable year; (B) which is attributable to the income of the taxable year or prior taxable years for which an election under this section is in effect; and (C) which the Secretary or his delegate is satisfied can be estimated with reasonable accuracy." \& 462 (d) (1). See Bierman \& Helstein, supra note 6, at 103-13.

Congress specifically envisioned deduction of such items as cash discounts for prompt payment, repairs or replacements made under a guarantee, sales returns and allowances, freight allowances, quality discounts, vacation pay and certain liabilities for self-insured injury and damage claims. H.R. Rep. No. 1337, 83d Cong., 2d Sess. A162-63 (1954).

20. See note 22 infra (citing cases where taxpayers had been denied reserve deductions related to prepaid income). See also Surrey \& Warren, Federal Inconse Taxation 370 (1953) (collecting other cases denying such deductions). 
what was in effect an earned income basis. ${ }^{21}$ Section 462 would have been particularly helpful to a firm unable to segregate its earned and prepaid income as required by section $452 . .^{22}$ For instance, a manufacturer selling appliances with a servicing guarantee attached could have reported a sale at face value and deducted both the cost of manufacturing the appliance and, under section 462, a reserve for the future expense of servicing it. ${ }^{23}$

Though still approving the policy behind sections 452 and 462 , Congress reluctantly repealed them retroactively ${ }^{24}$ in order to safeguard the level of feder-

21. The problems presented under $\$ 452$ (deferrals of prepaid income) and $\S 462$ (reserves for estimated future expenses) may be considered separately. See Hoffman, supra note 11, at 921; Wagman, supra note 9, at 713; Note, 18 LA. L. Rev. 215, 218 (1957) ("closely related but absolutely different problems"). In discussing $\$ 462$, Congress did not consider the section as relating to prepaid income. See, e.g., S. REP. No. 372, 84th Cong., 1st Sess. 2, 7 (1955).

Yet, $\S \$ 452$ and 462 overlapped to a degree. Many of the reserves allowed under $\S 462$ concerned expenses which were directly related to prepaid income. Section 462 therefore presented one method of approaching true accrual taxation. See SURREy \& WARREN, op. cit. supra note 20, at 362 (dual methods of reporting advance payments-defer reporting prepayments or include same in gross income while deducting a reserve). Although prepayments were reported prior to being earned, they were taxed on an earned-income basis. This Note is concerned with $\$ 462$ only in so far as reserves thereunder would affect prepaid income, $\varepsilon . g$., reserves for future expenses under servicing guarantees and maintenance contracts. But many of the same policy considerations presented in this Note apply with only slight variation to other types of reserves permitted under $\$ 462$, such as reserves for vacation pay. See, generally, Dakin, The Change From Cash to Accrual Accounting for Federal Incone Tax Purposes-Pyramided Income, Double Deductions and Double Talk, 35 Taxes 782 (1957).

22. For decisions denying reserve deductions under these circumstances, see Capital Warehouse Co. v. Commissioner, 171 F.2d 395 (8th Cir. 1948) (payments for picking up, storing and delivering merchandise received when merchandise first stored); Hamilton Neon Sign Co., 1 CCH Tax Ct. Mem. 126 (1942) (sales contract with maintenance clause); Amalgamated Housing Corp., 37 B.T.A. 817, 829 (1938), aff'd, 108 F.2d 1010 (2d Cir. 1940) (lessor's agreement to renovate apartments); W. J. Scholl Co., 30 B.T.A. 993 (1934) (ventilating contracts with attached one or two year guarantees); Quality Roofing Co., 16 B.T.A. 1370 (1929) (guaranteed roofing contract); Chapin Constr. Co., 3 B.T.A. 25 (1925) (contract to pave road and maintain in good condition for a period of years; payment received upon completion of paving); Uvalde Co., 1 B.T.A. 932 (1925) (same). For cases permitting deduction, see Schuessler v. Commissioner, 230 F.2d 722 (5th Cir. 1956), discussed notes 35-36 infra and accompanying text; Pacific Grape Products Co. v. Commissioner, 219 F.2d 862 (9th Cir. 1955), discussed note 38 infra; Moloney Elec. Co., P-H 1942 T.C. Mem. Dec. \f 42405 (payments for transformers sold with one year guarantee; inadequacy of merchandise became apparent in year sold).

23. See H.R. REP. No. 1337, 83d Cong., 2d Sess. A162 (1954) ( 462 intended for use on guarantees).

24. Act of June 15, 1955, c. 143, 69 Stat. 134. The House Committee on Ways and Means went on record as favoring further efforts to achieve the objectives of $\S \S 452$ and 462. H.R. REP. No. 293, 84th Cong., 1st Sess. 3 (1955). The Senate Finance Committee stated its intention to report out legislation at an early date, believing it "essential that the income tax laws be brought into harmony with generally accepted accounting principles." S. Rep. No. 372, 84th Cong., 1st Sess. 6 (1955). The Senate realized that recent cases had created uncertainty as to the deductibility of estimated expenditures. Congress 
al tax receipts. ${ }^{25}$ Excessive loss of revenue was feared during the first year in which accrual taxpayers would use the new sections. Under section 462 , deductions could be taken in that year for both present expenses attributable to prepaid income taxed in prior years under a claim of right theory, and for reserves for future expenditures incident to earning prepayments reported during the current year. ${ }^{26}$ Similarly, under section 452 , prepayments acquired during the year would be excluded from gross income while current expenditures related to past income would still be deductible. ${ }^{27}$ Occurring only during the year of transition, revenue losses from double deductions under section 462 and the limited gross income under section 452 were nonetheless considered too great to permit placing the taxation of prepaid income on a true accrual basis.

recommended to the Treasury Department that its rulings be modified to permit all publishers to defer prepaid income. Id. at 5. Nevertheless, the Secretary of the Treasury advised the Chairman of the Ways and Means Committee that the Treasury Department would not "consider the repeal of section 452 as any indication of congressional intent as to the proper treatment of prepaid subscriptions ... either under prior law or under other provisions of the 1954 Code." H.R. REP. No. 293, 84th Cong., 1st Sess. 5 (1955).

Upon repeal, taxpayers who had already followed $\$ \$ 452$ and 462 on 1954 returns were faced with an increased tax liability. Accordingly, Congress provided that a taxpayer so affected, filing a timely statement (form 2175) with his District Director of Internal Revenue, and paying the increase before December 12, 1955, was excused from payment of interest if he had reasonably interpreted $\$ \$ 452$ and 462 . "In no event [was interest to] ... be assessed [because of an] ... increase in tax resulting from a repeal of such sections prior to June 16,1955 . . ." Sporrer, supra note 1 , at 56.

25. Early in 1955, the Secretary of the Treasury wrote to the Committee on Ways and Means that: "Our studies now have proceeded far enough to indicate clearly that many taxpayers are planning to use these provisions [\$\$ 452 and 462] to defer income and create deductions in excess of anything contemplated at the time they were proposed." 101 CoNG. REc. 3686 (1955). The expected loss from $\$ \S 452$ and 462 had been estimated at $\$ 47,000,000$ for the fiscal year 1955. Id. at 3688. But as returns were filed, the estimate was revised to $\$ 500,000,000$ by the American Institute of Accountants. See S. REP. No. 372, 84th Cong., 1st Sess. 3 (1955). Actually, changes under $\$ \$ 452$ and 462 merely accelerated the tax loss which would normally occur under the claim of right approach upon the termination of the taxpayer's business. See text following note 13 supra.

26. See S. REP. No. 372, 84th Cong., 1st Sess. 4 (1955) ; Dakin, supra note 21, at 794: "[T] $[$ he real bette noire was the double deduction, not for new and novel expenses, but for expenses about which there could be no question and which had been estimated for normal corporate purposes for years."; Wagman, supra note 9, at 715-16. See also Freeman, Tax Accrual Accounting for Contested Items, 56 Micr. L. Rev. 727, 746 (1958) ("[T]he repeal was to close the door to double deductions and too large adjustments in one year"). Section 462 granted the Treasury Department discretionary power over items for which an estimated expense reserve could be established and the amounts includible in such reserve. But believing that the exercise of such power would result in excessive litigation, the Secretary asked for retroactive repeal pending further study. See S. REP. No. 372, 84th Cong., 1st Sess. 4-5 (1955).

27. Only one tenth of the estimated $\$ 500,000,000 \$ 452$ and 462 tax lass was due to $\S$ 452. See Hearings Before the Sentate Finance Conmittee on Prepaid Income and Reserves for Estimated Expenses, 84th Cong., 1st Sess. 21 (1955). See also Sporrer, supra note 1 , at 57 (had $\S 452$ stood alone, it probably would not have been repealed). 
Repeal of sections 452 and 462 revived the importance of case law authority on prepaid income taxation. ${ }^{28}$ The Commissioner has insisted that taxpayers report prepayments in the year of receipt ${ }^{29}$ and won acceptance for his view in the Tax Court and several courts of appeals. ${ }^{30}$ As a result, income from coupons entitling the bearer to such services as dance lessons and television repairs was held to be taxable upon the sale of the coupons rather than the performance of the service. ${ }^{31}$ Two circuits, however, have treated prepaid income in a manner

28. Sections 452 and 462 applied only to cases arising under the 1954 Code. No cases were reported during the six month interim between passage and repeal of these provisions. And since the repeal was retroactive, cases will never arise under them. Sections 441, 446, 451 and 461 , the only provisions now dealing with prepaid income, are re-enactments of the 1939 Code. Int. Rev. Code of 1939, $\$ \S 41,42,43,53$ Stat. 24. Cases interpreting the 1939 Code therefore take on special significance. The argument has been made that $\$ \S 441$, 446,451 and 461 should not be interpreted to allow what repeal of $\$ \$ 452$ and 462 sought to foreclose. See Wolder, sitpra note 10 , at 540 (raising and rejecting this argument).

29. Many taxpayers have refused to report income until earned, see cases cited note 30 infra, and have relied on the following cases rejecting application of claim of right doctrine. Beacon Publishing Co. v. Commissioner, 218 F.2d 697 (10th Cir. 1955), discussed in text at notes 33-34 infra; Clinton Hotel Realty Corp. v. Commissioner, 128 F.2d 968 (5th Cir. 1942) (advance rent characterized as a security deposit rather than income); Portland Cremation Ass'n v. Commissioner, 31 F.2d 843 (9th Cir. 1929) (advances on graveyard plots not reportable until service actually performed); Veenstra \& DeHaan Coal Co., 11 T.C. 964 (1948) (advances received on executory contract for purchase of coke would ripen into income only when transaction completed by delivery); Summit Coal Co., 18 B.T.A. 983 (1930) (receipts, viewed as advances of capital with which taxpayer was to purchase goods for retail sale, did not constitute income until recoupment was made from deliveries). Accord, Harrold v. Commissioner, 192 F.2d 1002 (4th Cir. 1951) (contractor allowed to accrue future estimated expenses of backfilling a strip mine). Ordinarily, the Commissioner requires that taxpayers discontinue deferred income reporting. See cases cited note 30 infra. In some instances, however, he has permitted deferrals of income. See Automobile Club v. Commissioner, 353 U.S. 180, 192 n.6 (1957) (dissenting opinion) (collecting regulations permitting deferrals). Publishers were allowed to report income from prepaid newspaper or magazine subscriptions on an accrual basis if such had been their consistent practice. See I.T. 3369, 1940-1 Cun. Bull. 46, as modified by Rev. Rul. 87, 1957-1 CuMr. Bull. 507.

30. See Automobile Club v. Commissioner, 230 F.2d 585 (6th Cir. 1956), aff'd, 353 U.S. 180 (1957); see also Fifteen Hundred Walnut Street Corp. v. Commissioner, 237 F.2d 933 (3d Cir. 1956) (rental payments taxable in years of receipt rather than in prior year when lease executed). Accord, Advertisers Exchange, Inc. v. Commissioner, 240 F.2d 958 (2d Cir. 1957) (income from prepaid advertising contracts). The Tax Court was especially persistent in denying deferments. See Bressner Radio, Inc., 28 T.C. 378 (1957) (income from prepaid television servicing contracts); Curtis R. Andrews, 23 T.C. 1026 (1955) (dance lessons). Accord, New Capital Hotel, Inc., 28 T.C. 706 (1957) (prepaid rent). These cases were consistent with the majority of the decisions prior to and during the interim between adoption and repeal of $\$ \$ 452$ and 462 . See note 5 supra. For circuits adopting the claim of right test prior to 1954, see South Dade Farms, Inc. v. Commissioner, 138 F.2d 818 (5th Cir. 1943); Renwick v. United States, 87 F.2d 123 (7th Cir. 1936) (advance rents taxable on receipt). But see Schuessler v. Commissioner, 230 F.2d 722 (5th Cir. 1956).

31. See Bressner Radio, Inc., supra note 30 (television repairs); Curtis R. Andrews, supra note 30 (dance lessons). 
consistent with accrual principles. ${ }^{32}$ In Beacon Publishing Co. v. Commissioner, ${ }^{33}$ the Tenth Circuit held that more than a right to unrestricted use was necessary to render advance subscription payments taxable in the hands of a publisher, and that only the portion which had been earned through publication was taxable income during the current year. ${ }^{34}$ Likewise, in Schuessler $v$. Commissioner, ${ }^{35}$ the Fifth Circuit permitted the deduction of a reserve for future expenditures under a prepaid furnace-servicing contract to be performed in subsequent years. ${ }^{36}$ Both courts emphasized that the Internal Revenue Code specifically permits the computation of taxable income under any regularly em-

32. See notes 33-38 infra and accompanying text. Some commentators have detected a trend foreshadowed by these two cases. See Dakin, supra note 21, at $790 \&$ n.47 (discussing a trend toward greater liberality); Hoffman, supra note 11, at 920; Wolder, supra note 10 .

33. 218 F.2d 697 (10th Cir. 1955). Although Beacon was decided during the interim between adoption and repeal of $\$ \$ 42$ and 462, the decision arose under the 1939 Code. Nevertheless, the court cited $\S \S 452$ and 462 as indicative of congressional policy favoring adoption of accrual accounting methods. Id. at $701 \& \mathrm{n} .3$.

34. Id. at 698-99. Holding that the Tax Court erred in applying the claim of right doctrine, the court of appeals stated:

"It [the Tax Court] gave no consideration to the fact that the taxpayer accounts for its income under the accrual method and will not incur the expenses necessary to earn the income until following taxable years. In other words, the tax court holds that advance payments received by a taxpayer, which are subject to income tax, must be returned in the year of receipt if owned or claimed by the taxpayer, regardless of the method of accounting, which has been adopted, or when the funds are actually earned. Such application of the rule limits the accrual method to that class of cases where money has been earned and the right to it has been fixed, but the receipt is delayed to a subsequent taxable period. The application of the doctrine would in most cases result in a distortion of an accrual taxpayer's true income." Id. at 700.

But the Tax Court seemingly ignored this criticism and continued to apply the claim of right doctrine. See E. W. Schuessler, 24 T.C. 247 (1955), rev'd, 230 F.2d 722 (5th Cir. 1956) ; Curtis R. Andrews, 23 T.C. 1026 (1955). The Tax Court's tendency to disregard circuit court decisions has been noted. See Comment, Heresy in the Hierarchy: Tax Court Rejection of Court of Appeals Precedents, 57 Colun. L. Rev. 717 (1957).

Beacon concerned an accrual taxpayer attempting to change from a claim of right basis to true accrual reporting. See text at notes 71-74, 76 infra.

35. 230 F.2d 722 (5th Cir. 1956).

36. With each furnace sold, the seller guaranteed to turn the furnace on and off for the next five years. He included the full sales price in gross income and deducted a reserve for estimated expenditures to be incurred in performing under the guarantee. The Tax Court recognized that the case presented the same basic issue as Beacon Publishing Co. v. Commissioner, 218 F.2d 697 (10th Cir. 1955), but still sustained the application of the claim of right doctrine, see E. W. Schuessler, 24 T.C. 247 (1955). In reversing, the Fifth Circuit emphasized that the petitioner's method of accounting came much closer to giving an accurate picture of his income than the method contended for by the Commissioner. $230 \mathrm{~F} .2 \mathrm{~d}$ at 723 . Schuessler involved a taxpayer apparently receiving prepaid income for the first time. See note 72 infra and accompanying text.

When the claim of right doctrine forced the reporting of prepayment upon receipt, many taxpayers tried to deduct future expenses attributable to these payments in order to achieve an "earned income" basis. See, e.g., Bressner Radio, Inc., 28 T.C. 378 (1957). But 
ployed accounting method which "clearly reflects income."37 The application of the accrual system to prepaid income was consequently upheld as giving a "correct picture" of actual earnings. ${ }^{38}$

Reasoning found persuasive in Beacon Publishing and Schuessler was presented to, and neither accepted nor rejected by, the Supreme Court in Automobile Club of Wichigan v. Commissioner. ${ }^{39}$ Petitioner claimed that, under its accrual accounting system, yearly membership dues could be allocated to gross income on a monthly basis. Specifically, only one half of the annual dues for a

the Tax Court rejected this approach, claiming that these deductions were too indefinite. See cases cited note 22 supra; SURREY \& WARREN, op. cit. supra note 20, at 370 (collecting cases).

37. 230 F.2d at $725 ; 218$ F.2d at 700 . The Int. Rev. Code of 1939, § 41, 53 Stat. 24, allows a return to be made "in accordance with the method of accounting . . . employed [by] . . . such taxpayer [unless] . . . the method employed does not clearly reflect the income ...." Treasury regulations specifically allowed accrual accounting methods. U.S. Treas. Reg. 118, $\$ 39.41-2$ (1953). Section 42 required "income [to be] . . . included in the gross income for the taxable year in which received by the taxpayer, unless, under methods of accounting permitted under section 41, any such anounts are to be properly accounted for as of a different period ...." (Emphasis added.) Int. Rev. Code of 1939, $\$ 42,53$ STst. 24. Since deferral of unearned income is patently a facet of accrual accounting, $\$ 42$ would seem to sanction it. On the other hand, application of the claim of right doctrine to prepayments results in an inaccurate reflection of income contrary to $\$ 41$. See Gelfand, The "Clain of Right" Doctrine, 33 TAXEs 726 (1955).

The 1939 Code allows deductions to be taken in the year "paid or accrued," depending upon the taxpayer's accounting methods, if income is clearly reflected. Int. Rev. Code of $1939, \S 43,53$ STAт. 24 . Taxpayers have argued that prepayment of income creates a liability on their part and therefore future expenses should be deductible when the income is received. But the "reserve deduction" method of accounting has been rejected by both the Commissioner and the Tax Court. See Surrey \& Warren, op. cit. supra note 20, at 370; Dakin, supra note 21, at 788; note 22 supra and cases cited therein.

With repeal of $\$ \S 452$ and 462 , INT. Rev. CODE of 1954, $\$ \S 441,446,451$ and 461 (formerly Int. Rev. Code of 1939, $\$ \$ 41,42$ and 43, 53 Stat. 24 ), become the only provisions applicable to prepaid income. See note 28 supra. Adoption of accrual accounting methods will have to be accomplished through interpretation of these provisions.

38. 230 F.2d at 725 ; see 218 F.2d at 700 . For cases reflecting a similar approach in slightly different contexts, see Hilinski v. Commissioner, 237 F.2d 703 (6th Cir. 1956) (cost of completing merchandise contracted for in the taxable year may be subtracted from the contract price received) ; Pacific Grape Products Co. v. Commissioner, 219 F.2d 862 (9th Cir. 1955) (allowing deduction of future expense for shipping goods sold during the taxable year). Extension of the Sixth Circuit's reasoning in Hilinski to prepaid income would result in a reversal of that court's pre $\$ \$ 452,462$ position. See, e.g., E. H. Sheldon \& Co. v. Commissioner, 214 F.2d 655 (6th Cir. 1954). But see Automobile Club v. Commissioner, 353 U.S. 180 (1957), affirming 230 F.2d 585 (6th Cir. 1956) (upholding use of claim of right doctrine as sole determinant of year of taxation).

39. 353 U.S. 180, rehearing denied, 353 U.S. 989 (1957). The right of a taxpayer to defer reporting prepaid income had previously been before the Court in Brown v. Helvering, 291 U.S. 193 (1934). But there the Supreme Court was not forced to reach the issue either; "no proof [existed] that the overriding commissions contain[ed] any element of compensation for services to be rendered in future years." Id. at 204. For a similar fact situation where deferment was specifically disallowed, see Pioneer Automobile Serv. Co., 36 B.T.A. 213 (1937). 
membership starting in July were reported in the year of receipt. ${ }^{40}$ The Commissioner insisted, however, that the entire amount was taxable since it was held under a claim of right. ${ }^{41}$ He was successful before the Tax Court and the Sixth Circuit. ${ }^{42}$ The Supreme Court, finding that the petitioner's system of deferment was "purely artificial" and bore "no relation" to the services rendered under the membership contract, ${ }^{43}$ upheld the Commissioner's determination as within his discretionary power to recompute taxable income when the taxpayer's accounting method does not "clearly reflect income." ${ }^{44}$ Thus, although it reached the same result as lower tribunals, ${ }^{45}$ the Court did so for different reasons. The Tax Court, while admitting that deferred reporting may portray the taxpayer's income, has nevertheless insisted that the "well-established" claim of right test must prevail. ${ }^{46}$ On the other hand, the Supreme Court merely stated that a particular petitioner's deferment of prepayments was not justified, and that the Commissioner might therefore ascertain income in accordance with another method of accounting. ${ }^{47}$ Despite these divergent approaches, the Tax Court, in subsequent cases, has cited Michigan Auto to affirm the Commissioner's employment of receipt as the exclusive occasion for taxing prepaid income. 48

The Tax Court's sweeping interpretation of the Supreme Court's opinion is unwarranted. The Internal Revenue Code grants the Commissioner power to compute taxable income by his own methods only if the accounting system used by the taxpayer fails clearly to reflect income. ${ }^{49}$ In reviewing the exercise of this power, a court must first determine the adequacy of the taxpayer's account-

40. 353 U.S. at 189. Annual dues received from a member were recorded in an account designated "Unearned Membership Dues." Each month, as dues were earned, one twelfth of the amount was transferred to the "Membership Income" account. Thus, if a member paid his dues in December 1945, petitioner's books recorded only one twelfth of the dues as income for 1945, and eleven twelfths as income for 1946.

41. Id. at 188-89.

42. Automobile Club, 20 T.C. 1033, 1047 (1.953) ("we hold that the entire amount of membership dues received by petitioner during the years here involved constituted income for the year in which received"), aff'd, 230 F.2d 585, 591 (6th Cir. 1956).

43. 353 U.S. at 189 . The Court stated that: "The pro rata allocation of the membership dues in monthly amounts is purely artificial and bears no relation to the services which petitioner may in fact be called upon to render for the member." Ibid.

44. Id. at 189-90. The Court stressed the statutory discretion vested in the Commissioner under $\S 41$ of the 1939 Code. See notes 28,37 supra.

45. See cases cited notes 5,30 supra.

46. Curtis R. Andrews, 23 T.C. 1026, 1032 (1955) (collecting cases). The Tax Court, in Automobile Club, 23 T.C. 1033 (1953), not only relied on claim of right, see note 42 supra, but also insisted that the petitioner's accounting system was inaccurate.

47. 353 U.S. at 189. See note 44 supra. For a discussion of the Court's holding, see Freeman, supra note 26, at 731.

48. Bressner Radio, Inc., 28 T.C. 378, 382-84 (1957) (citing Michigan Auto three times); New Capital Hotel, Inc., 28 T.C. 706 (1957).

49. Int. Rev. Code of 1939, § 41, 53 Stat. 24 (now INT. Rev. Code of 1954, § 446). See notes 28,37 supra. 
ing system $;^{50}$ and only if it is found inadequate should the court, in deference to the Commissioner's discretion, accept his computation if reasonable. ${ }^{51}$ Thus, where a petitioner misapplied the accrual accounting system, the Commissioner was allowed to recompute income on a cash basis despite the fact that a properly used accrual system would have been a more exact reflection of income. ${ }^{52}$ And since the claim of right approach approximates the cash system, ${ }^{53}$ its employment in Michigan Auto-where taxpayer's accrual accounting was unduly imprecise-fell within the Commissioner's discretion. ${ }^{54}$ By permitting the Com-

50. See, e.g., Maloney v. Hammond, 176 F.2d 780 (9th Cir. 1949) (Commissioner had not shown petitioner's method incorrect); Osterloh v. Lucas, 37 F.2d 277 (9th Cir. 1930) (same); William H. White, Sr., $12 \mathrm{CCH}$ Tax Ct. Mem. 996, 997 (1953) (petitioner's accounting system "must be accepted for the purpose of computing the tax unless it does not clearly reflect the income of the business"). See also Schram v. United States, 118 F.2d 541 (6th Cir. 1941) ; Bancroft v. United States, 49 F. Supp. 476 (Ct. Cl. 1943); Nibley-Mimnaugh Lumber Co., 32 B.T.A. 791 (1935); Gelfand, supra note 37, at 726 ("The Commissioner is given the right to use his own method only if . . the taxpayer's method does not clearly reflect income"). See, generally, 3 CCH 1958 Stand. FED. TAX REP. \2820.02.

51. See Brown v. Helvering, 291 U.S. 193, 204 (1934) (emphasizing Commissioner's wide discretion in instituting a change). Burden of proof is on the taxpayer to show the Commissioner erred in computing the tax. See Helvering v. Taylor, 293 U.S. 507 (1935); Federal Nat'1 Bank v. Commissioner, 180 F.2d 494 (10th Cir. 1950) ; 3 CCH 1958 STAND. FED. TAX Rer. $\llbracket 2817.10$ (collecting cases). But see Bradstreet Co. v. Commissioner, 65 F.2d 943, 945 (1st Cir. 1933) ("The burden to adopt a method that will clearly reflect the income is on the Commissioner equally as well as on the taxpayer"). The accounting methods employed by the Commissioner need not be the most accurate available. In re Newman, 94 F.2d 108 (6th Cir. 1938) (Commissioner could employ cash system for recomputation even though accrual system more accurate). Accord, Boca Ceiga Development Co., 25 B.T.A. 941 (1932) ; J. P. Bass Publishing Co., 12 B.T.A. 728 (1928). The Commissioner has utilized various methods for computing income, including some which the taxpayer probably would not be allowed to use. See, e.g., Holland v. United States, 348 U.S. 121 (1954) (increase in net worth); Maurice Cross, 24 B.T.A. 1079 (1931) ("unit mark-up" or "percentage basis"). Approved standard methods of accounting will almost automatically be regarded as reflecting income. See Josef C. Patchen, 27 T.C. 592 (1956). See also Proposed U.S. Treas. Reg. \& 1.446-1(a) (2) (1956); 3 CCH 1958 Stand. Fen. Tax Rep. \2815.01. But such systems must be properly applied. Russell v. Commissioner, 45 F.2d 100 (1st Cir. 1930) (recapitulation rejected because Commissioner inaccurately utilized accrual methods).

52. In re Newman, supra note 51. (petitioner's attempt to utilize single-entry bookkeeping in applying accrual accounting resulted in distorted reporting of income; court permitted Commissioner to recompute on cash basis, but admitted that accrual basis might be more "scientific") ; see Boca Ceiga Development Co., supra note 51 (same result although court justified Commissioner's use of cash system by finding that taxpayer's system, claimed to be accrual, was actually cash); J. P. Bass Publishing Co., supra note 51 (similar).

53. Beacon Publishing Co. v. Commissioner, 218 F.2d 697, 700 (10th Cir. 1955); Wolder, Deduction of Reserves for Future Expenses and Deferring of Prepaid Income, 34 TAXES 524, 526 (1956).

54. The cash system is almost always acceptable. See Osterloh v. Lucas, 37 F.2d 277, 278-79 (9th Cir. 1930): "The case turns largely upon what is meant by the requirement that the method of accounting shall clearly reflect the income. If this requirement is absolute, it is safe to say that books kept on the basis of cash received and disbursed will 
missioner's determination, however, the Supreme Court did not imply that the claim of right test was the only acceptable standard for taxing prepayments. ${ }^{50}$ In fact, if the club's system of deferments had borne a realistic relation to services rendered, the Supreme Court might well have sustained it from the Commissioner's attack, 56 for the Court specifically reserved "opinion on the correctness of the decisions in Beacon or Schuessler." The dissent, moreover, criticized the decision as regrettably "bypass[ing] the Commissioner's 'claim of right' argument." "ss In summary, Michigan Auto has not precluded lower court acceptance of the Beacon Publishing approach.

Michigan Auto may nonetheless have limited the implications of Beacon Publishing. In rejecting the pro rata allocation of prepaid yearly dues to gross income, the Court stressed that because services were only provided upon a member's demand, neither the time nor extent of the club's performance was fixed. ${ }^{59}$ Beacon was distinguished as a case concerning prepayments under a contract requiring the taxpayer to perform certain services on a specified date. ${ }^{00}$

rarely, if ever, reflect the true income, because nearly always at the end of a tax year accounts due the taxpayer will remain uncollected and some of his own obligations will remain unpaid. But we do not think that any such literal construction was contemplated. In our opinion, all that is meant is that the books shall be kept fairly and honestly; and when so kept they reflect the true income of the taxpayer within the meaning of the law." See also William H. White, Sr., 12 CCH Tax Ct. Mem. 996 (1953) (cash method acceptable though inaccurate) ; Estate of Julius I. Byrne, 16 T.C. 1234 (1951); Daily Record Co., 13 B.T.A. 458 (1928); 3 CCH 1958 Stand. FED. TAx REP. If 2820.28 (collecting cases). But see Boynton v. Pedrick, 228 F.2d 745 (2d Cir. 1955) (in certain circumstances Commissioner could require taxpayer's utilizing accrual method). Where inventories are used, only accrual accounting is allowable for those items. See Herberger v. Commissioner, 195 F.2d 293 (9th Cir. 1952) ; 3 CCH 1958 Stand. Fed. TAX Rep. |f 2820.29.

55. See Note, 18 LA. L. Rev. 215, 217 (1957) ("The majority opinion failed to pass upon the propriety of using the 'claim of right' rule to determine the year in which prepaid income is taxable"). See also Freeman, stepra note 26, at 731 ("If in the Automobile Club of Michigan case the Supreme Court has chosen the claim of right rule in preference to sound accrual accounting, then the case is to be lamented. But it is possible that the Supreme Court did not go this far"). The Court only mentioned claim of right in stating the arguments advanced by the parties. 353 U.S. at 188.

56. Hoffman, Acconnting Treatment Counts in Determining Net Taxable Income, 35 Taxes 918, 921 (1957) (decision hints of "conditions under which the Supreme Court might find deferred income acceptable").

57. 353 U.S. at 189 n.20.

58. Id. at 192 (dissenting opinion of Mr. Justice Harlan). The dissent rejected the applicability of claim of right in the instant case and followed the reasoning of Beacon Publishing Co. v. Commissioner, 218 F.2d 697 (10th Cir. 1955), discussed notes 33-34 supra and accompanying text.

59. 353 U.S. at 189 n.20.

60. Id. at 189 . In Beacon, both prepayments and services were reasonably certain because petitioner published a daily newspaper. The court apparently disregarded the fact that the length of the paper might vary.

The Supreme Court also distinguished Schuessler v. Commissioner, 230 F.2d 722 (5th Cir. 1956). 353 U.S. at 189. Though the service performed by Schuessler-turning furnaces on and off-was contingent on the purchaser's demand, the dates of the servicing, 
The Court thus implied that deferments could only be justified as clearly reflecting income if the taxpayer could definitely ascertain both the quantum of services to be performed in earning the prepaid income and when such performance would occur.

When the amount and cost of performance can be accurately estimated, an indefinite time of performance does not prevent returns from reflecting true earnings. For example, a dance studio contracting to provide lessons upon the purchaser's demand could be allowed to defer reporting advance payments until instruction is actually given. ${ }^{61}$ Since the lessons would be approximately equal in cost and their total number fixed, the taxpayer could easily match expense and income by reporting that portion of the prepayment representing the percentage of the contract completed during a given year. Furthermore, by limiting the life of the contract, the taxpayer could assure the courts that payments for unused lessons would be reported within a reasonable time from the year of receipt. ${ }^{2}$ Of course, if the studio could select the dates of instruction under the contract, it could actually set the year in which prepayments would be taxed. But unilateral seller determination of the time of performance rarely exists $;^{63}$ nor could it significantly increase opportunities for income tax postponement beyond those generally available in the 1954 Code. ${ }^{64}$ Thus, the accrual taxpayer who can ascertain the extent of his future performance in earning advance payments can formulate a system of deferment which complies with the statutory standard of "clearly reflecting income."

When, as in Michigan Auto, the amount of services to be provided is indefinite, proper application of accrual principles becomes more difficult. Unlike the dance studio, the automobile club cannot postpone reporting a member's

being dependent upon the changing of the seasons, were ascertainable with reasonable accuracy in advance. Ibid. See Freeman, Tax Accrual Accounting for Contested Itenw, 56 Mich. L. REv. 727, 731 (1958).

61. See, e.g., the fact situation in Curtis R. Andrews, 23 T.C. 1026 (1955).

62. Section 452 (b) required that all prepayments be reported as income within six years.

Taxpayers often include time limitations in their regular accounting system. See Curtis R. Andrews, supra note 61.

63. The typical contract resulting in unearned income specifies dates when goods are to be delivered or services to be rendered. See Schuessler v. Commissioner, 230 F.2d 722 (5th Cir. 1956) (services) ; Beacon Publishing Co. v. Commissioner, 218 F.2d 697 (10th Cir. 1955) (goods).

64. Despite the concept of constructive receipt, the cash accounting system still provides opportunities for postponing income tax. See 2 MERTENs $\$ \$ 11.05,11.06,12.22,12.39$; $3 \mathrm{CCH} 1958$ Stand. Fed. TAx Rep. If 2820.027. Present Internal Revenue Code provisions malke income and deductions legally deferrable under specified circumstances. INT. REv. CODE of 1954, $\$ 171$ (b) (bond premiums may be amortized over the period of years to which such premium is attributable); $i d . \$ 172$ (provisions for allocation over a period of years of net operating losses) ; $i d$. $\$ 453$ (installment contract profits may be reported as received in proportion to the total contract price); $i d . \$ 461$.(c) (1) (real property taxes related to a definite period of time may be accrued ratably over that period); $i d . \S 1303$ (provision for allocating back pay over a period of years). 
advance payments until he requests services. The total assistance that he might need over the contract is unpredictable, and the percentage of dues allocable to income upon performance of a certain activity therefore cannot be ascertained. Furthermore, the Supreme Court in Michigan Auto justifiably proscribed monthly allocations of one twelfth of annual dues to gross income, since no proof was offered to show that prepayments deferred strictly according to lapsed time were matched against related expenses. ${ }^{65}$ Correlation of revenue and expense could be approximated, however, by determining deferments for a given month on the basis of statistical records for that month in the past.68 Thus, an automobile club could defend its method of allocating any individual's dues by demonstrating the average services requested by a member for a particular period. ${ }^{\mathbf{6 7}}$

This type of statistical evidence could be utilized not only by accrual taxpayers who defer reporting income but also by those who receive payments

65. A member might demand far more services in, say, January than in June. But see Note, 18 LA. L. REv. 215, 217 (1957) (not mentioning this possibility but criticizing the Court's refusal to allow strict monthly allocation of annual dues). This commentator suggested that the club's method of allocation was justified since the club "did know exactly how much it was being paid each month to render the services." Ibid. The club was not selling twelve monthly memberships, however, but a single membership for the entire year.

66. In Michigan Auto, no evidence was offered to prove, even by averaging statistics, that apportionment of one twelfth of the membership dues to each month truly reflected the liabilities. See Brief for Petitioner, pp. 22-28, Automobile Club v. Commissioner, 353 U.S. 180 (1957).

On rehearing, the petitioner claimed that its expenditures were constant throughout the year. The Court's denial of the rehearing does not indicate that it considered such evidence irrelevant. Varying reasons may lead to such a denial. Cf. Maryland v. Baltimore Radio Show, 338 U.S. 912, 917 (1950) (denial of certiorari imports no expression of opinion upon the merits of the case when reasons for denial are not given). Michigan Auto's major issue was the legality of a retroactive reversal of the club's tax-exempt status. See 353 U.S. at 180-86. As prepaid income was incidental to the main issue, the Court might not have considered this question, by itself, an important enough problem to grant rehearing. See Note, 18 LA. L. REv. 215, 218 (1957).

67. See Hoffman, supra note 56, at 921; cf. Steger, On the Theoretical Equity of an Averaging Concept for Income Tax Purposes, 13 TAx L. Rev. 211 (1958) (discussing the related problem of averaging income). In Freeman, supra note 60, at 731, the author suggests that the Supreme Court might have permitted Michigan Auto to use a reserve deduction method of accounting for prepaid income. But in distinguishing both Beacon (deferral) and Schutessler (reserve deduction), the Court indicated it was primarily interested in the indefiniteness of timing, not which of the two alternative methods of accounting was used. See text at notes 16-23 supra.

As this issue went to press, the Senate adopted a bill which would permit "nonprofit corporations, such as auto clubs, principally engaged in providing services for members in return for dues or fees" to spread the income from those dues over the service period. 4 P-H FED. TAX SERV. II 32299 (1958) (summarizing bill). Although passage of this bill would solve the problem of reporting prepaid income for automobile clubs, it fails to aid the entire class of taxpayers who cannot estimate either the time or amount of performance to be rendered to an individual customer. Thus, firms selling service guarantees would still be governed by the Michigan Auto decision and would therefore face the problems presented in this Note. 
which are only partially earned, report the entire amount upon receipt, and deduct a reserve for future expenditures relating to the unearned portion. ${ }^{68}$ Michigan Auto does not deny that a statistical correlation of average performance under comparable contracts may serve as adequate evidence that deferments and reserves are being used to reflect income accurately. ${ }^{69}$ Moreover, to find such a denial in the decision would be to create a conflict with the congressional desire to facilitate taxpayer justification of accounting methods. Having anticipated that sections 452 and 462 would be used for items like club dues and advance payments on service guarantees, Congress could not have expected taxpayers to produce more than statistical proof of the appropriateness of reserves and deferrals. ${ }^{70}$ Repeal of those provisions because of fiscal considerations involved no suggestion that Congress had altered its previous position on evidentiary standards.

Nevertheless, Congress' paramount concern in maintaining revenues, as expressed by the repeal of sections 452 and 462 , suggests a limitation upon the use of accrual principles. Retention of the strict claim of right test may be necessary to prevent the deduction of current expenditures related to prior years from a gross income diminished by deferments, or the deduction of both current and future expenses from a single year's gross income. ${ }^{71}$ In two areas, however, these revenue losses would not occur. One comprises taxpayers receiving prepaid income for the first time. ${ }^{72}$ Here, present expenditures, if any, would de-

68. Of course, this latter procedure results in paying a tax on the net profit in the year of receipt. Although most taxpayers would probably prefer to postpone reporting the income, the reserve deduction method is often used. See text at note 22 supra. In most instances, these reserve deductions have been disallowed. See note 20 supra. Some courts have insisted upon absolute certainty as to the amount of the taxpayer's future liability before allowing a reserve deduction. See Capital Warehouse Co. v. Commissioner, 171 F.2d 395 (8th Cir. 1948) ; Spencer, White \& Prentis, Inc. v. Commissioner, 144 F.2d 45 (2d Cir. 1944). See, generally, Freeman, supra note 60, at 733-42; Comment, Accrual: The Uncertain Concept of Certainty-A History of the All Events Test, 21 U. CHI. L. REv. 293 (1954). A few courts have been satisfied if "the amount, although not definitely ascertained, is susceptible of estimate with reasonable accuracy in the tax year . ..." Harrold v. Commissioner, 192 F.2d 1002, 1006 (4th Cir. 1951). See also Central Cuba Sugar Co. v. Commissioner, 198 F.2d 214 (2d Cir. 1952). These decisions indicate that statistical correlation might be adequate proof of accuracy. See, generally, Wolder, supra note 53 , at 528 .

69. The established company could base estimates upon past records, while the new firm could utilize general industry records.

70. See H.R. Rer. No. 1337, 83d Cong., 2d Sess. 48 (1954). The House Ways and Means Committee anticipated that deductions would be taken for future expenses under guarantees if "average cost ... can be estimated with reasonable accuracy ...." Id. at A162.

71. Fear of revenue loss from deductions, coupled with deferments or double deductions, induced repeal of $\$ \S 452$ and 462. See notes 25-27 supra and accompanying text.

72. See, e.g., Your Health Club, Inc., 4 T.C. 385 (1944); South Tacoma Motor Co., 3 T.C. 411 (1944). Applying claim of right in this situation would increase federal revenue during the first year because deferrals and deductions would be disallowed. But Congress, repealing $\$ \$ 452$ and 462 , was not concerned with postponement of income reporting into the next year so long as payments were eventually reported. Double deductions and de- 
pend on the current year's income; taxpayers therefore should be allowed to account for prepayments through either the deferment or "reserve deduction" method. Similar treatment should be accorded a second group consisting of persons who receive advance payments and who have consistently followed accrual principles for prepaid income on previous tax returns. ${ }^{73}$ Since the double deduction problem and its deferral counterpart-which underline the repeal of sections 452 and $462-$ only arise when the system of reporting prepaid income is changed, no necessity exists for forcing these taxpayers to assume the inequities inherent in claim of right doctrine. ${ }^{\mathbf{7 4}}$

Limited to these two areas, general judicial acceptance of the deferments and "reserve deductions" of Beacon Publishing and Schuessler would permit rational treatment of prepaid income without impairing revenue production. ${ }^{75}$ True, an accrual taxpayer presently accepting a strict claim of right basis would be forced to continue with its inequities or pay the tax adjustment required for permission to make a "change in accounting method."76 This discrepancy

ductions coupled with deferments provoked the repeal, since here the tax loss would not be recouped in later years. Thus, only losses occurring in the year of transition to accrual reporting must be considered when formulating an approach which will satisfy both aims of Congress-maintaining revenues and correlating business and tax accounting. See notes 24-27 supra and accompanying text.

73. Some taxpayers have not yielded to the claim of right doctrine until compelled to do so by court proceedings. See Automobile Club v. Commissioner, 353 U.S. 180 (1957) ; Curtis R. Andrews, 23 T.C. 1026 (1955).

74. If placed on a claim of right basis, taxpayers previously deferring prepaid income, or establishing "reserve deductions," would have an unrealistically high gross income in the year of transition. See text at notes 14-15, 71 supra.

75. Beacon Publishing Co. v. Commissioner, 218 F.2d 697 (10th Cir. 1955), discussed notes 34-35 supra and accompanying text, permitted petitioner, an accrual taxpayer, to change from a claim of right to an earned income method of reporting income. Prior to 1943, prepaid subscriptions had been reported in the year of receipt; afterwards, such payments were deferred. Although the changeover produced a revenue loss in 1943, the court ignored it. Beacon can be explained, however, by the fact that the case came before the court in January 1955, two months before Congress began the process of repealing $\$ \S 452$ and 462. See 101 Cong. REc. 3686 (1955). Therefore, legislative fear of revenue losses had not yet been articulated. Also, the Internal Revenue Service had promulgated rules permitting the publisher who consistently followed accrual methods to continue with that system I.T. 3369, 1940-1 CUM. BurL. 46. Indications are that Congress will amend these rules in the 1958 legislative session by adopting a bill which will permit all classes of publishers to defer reporting prepaid income. See 4 P-H FED. TAX SERv. ff 32299 (1958).

76. INT. Rev. CoDE of 1954, § 446(e), and U.S. Treas. Reg. 118, § 39.41-2(c) (1953), under the 1939 Code, require the Secretary or his delegate to approve changes in accounting method. Transitions usually necessitate adjustment of the changeover year's return in order to prevent double deductions on a single expenditure or permanent exclusion of payments from gross income. See INT. Rev. Code of 1954, $\$ 481$. The Commissioner has wide discretion in prescribing the requisite adjustments. Ross v. Commissioner, 169 F.2d 483, 489 (1st Cir. 1948). On adjustments generally, see Richardson, Accounting Methods and Changes Therein, 35 TAxes 924 (1957) ; 3 CCH 1958 Stand. Fed. TAx Rep. $\llbracket 2982$.

In Beacon, the court held that a taxpayer shifting from a claim of right to a deferment system of reporting prepaid income had not changed his accounting method in the statutory 
seems justified in view of the fiscal decision involved, for general adoption of a tax scheme modeled after sections 452 and 462 necessarily rests with Congress. ${ }^{77}$ Meanwhile, a shift from claim of right to accrual returns should require Treasury approval in order to limit revenue losses resulting from reporting-system transitions. Since firms which have consistently followed correct accounting theory or are returning prepaid income for the first time could do so without the Treasury's permission, the judiciary would be competent to permit them to utilize Beacon-Schuessler doctrine. Of course, these two classes of taxpayers could be relegated to the same claim of right treatment imposed on other accrual taxpayers; however, neither the Code nor legislative policy insists upon a uniform method of reporting prepayments among all accrual taxpayers. ${ }^{78}$ Thus, the proposed approach, while consonant with present law, would foster adoption of proper accrual accounting and there-

sense. The transition was considered as correcting a previous error. 218 F.2d at 702 . But precedent is against the Beacon reasoning. Although the taxpayer was generally on an accrual basis, by using receipt to determine the year of inclusion, he had been on a cash basis with respect to prepayments. Thus, his shift to a deferral system constituted a change from a cash to an accrual basis. And changes in the treatment of a single item require the Commissioner's approval. Proposed U.S. Treas. Reg. $\$ 1.446-1$ (e) (2) (1956). For cases considering transitions somewhat similar to Beacon as statutory changes, see Erica Giepen, $16 \mathrm{CCH}$ Tax Ct. Mem. 20 (1957) (accrual taxpayer creating reserve for sales refunds had changed method) ; Pacific Vegetable Oil Corp., 26 T.C. 1 (1956), rev'd on other grounds, 251 F.2d 682 (9th Cir. 1957) (initiation of reserve for copra shrinkage during transportation required approval) ; Advertisers Exchange, Inc., 25 T.C. 1086 (1956) (accrual taxpayer's accounting revision so as to defer contract prepayments required Commissioner's consent). See also Wetherbee Elec. Co. v. Jones, 73 F. Supp. 765 (W.D. Okla.), appeal dismissed, 164 F.2d 278 (10th Cir. 1947). There, the court held that an allocation of overhead expenses between completed and incompleted contracts was a correction of error, not a change of method. The taxpayer was operating on a completed contract basis which specifically requires such apportionment of expenses. See U.S. Treas. Reg. 118, $\$ 39.42-4$ (1953). Since postponement of deduction was statutorily compelled, the taxpayer's commencement of that practice was properly considered as not requiring Commissioner approval. But in Beacon, petitioner's change was entirely voluntary.

77. It has been suggested that re-enactment of $\$ \$ 452$ and 462 should incorporate these provisions: enumeration of deductible items; taxpayer choice of items to be deducted; revenue loss to be amortized over period of years. Wagman, Sections 452 and 462 : Stormy Past but a Bright Tomorrow, 33 Taxes 711, 715-17. The proposal to extend the transitional period to several years is supported by other authorities. See S. REP. No. 372, 84th Cong., 1st Sess. 3 (1955) (American Institute of Accountants). Similar stretch-out periods are used in other tax areas. See INT. Rev. CoDE of 1954, § 172(b) (1) (eight year stretch-out for net operating losses); id. $\S 174$ (same for research and experimental expenditures); id. $\S 248$ (five year stretch-out for deduction of organizational expenses); id. $\S 481$ (b) (1) (three year allocation if income telescoped by change in accounting methods).

78. The Senate expressed concern over the present status "where some taxpayers are able to defer prepaid income while others are not ...." S. REP. No. 372, 84th Cong., 1st Sess. 6 (1955). To remedy this situation, it promised to report out legislation. Ibid. Present legislative inactivity indicates that maintenance of revenues ranks over equality of treatment. In fact, the Senate itself promoted further disparity between taxpayer treatment by recommending that a special class, publishers, be allowed to defer prepaid income. 
by reduce the revenue loss which will occur when Congress re-enacts section 452-462 type legislation. ${ }^{79}$

Id. at 5. For similar reactions in the House, see H.R. REP. No. 293, 84th Cong., 1st Sess. 5 (1955).

The Code specifically allows disparity in treatment. INT. REv. Code of 1954, § 446 (cash or accrual accounting permitted). See also I.T. 3369, 1940-1 Cun. Bull. 46, as modified by Rev. Rul. 87, 1957-1 CuM. Bull. 507.

79. Congress has indicated its intent eventually to re-enact $\$ \S 452$ and 462 . See note 24 supra.

Alteration of economic conditions may have changed congressional attitude toward the revenue loss which would accompany re-enactment. During periods of economic contraction, government fiscal and monetary policies are aimed at increasing funds available for private spending and investment. Although tax cuts further this goal, they tend to be inflationary because political expediency may prevent restoration of the cuts after economic recovery. But adoption of $\$ \$ 452$ and 462 will have the effect of a tax cut only for the transitional year. Thus, present re-enactment would both eliminate inequities and provide a business stimulant without any persisting economic consequences.

Indications are that Congress is adopting an industry-by-industry approach for reenacting $\$ \$ 452$ and 462 . See notes 67,75 supra (discussing a bill before Congress which would place automobile clubs and publishers on a $\S 452$-type system of reporting prepaid income). 